\title{
Franken 1978: Koperníkovský obrat v exilové organizaci Opus bonum
}

\section{Franken 1978: Copernican Revolution in the exile organization Opus Bonum}

Ondřej Bakeš / ondrej.bakes@gmail.com

Historický ústav, Filozofická fakulta, Masarykova univerzita

\begin{abstract}
The exile organization Opus Bonum has become more widely known by organizing the symposiums in the Bayern town Franken. Especially the first meeting in February 1978 became a milestone in the history of the association and one of the most important activities of exile after the Soviet occupation in 1968. On a common platform debated the representatives of so-called "winners" together with "losers" from February 1948, e.g. Zdeněk Mlynár and Pavel Tigrid The focus of the organization thus changed from the original cultural-religious one to a discussion meeting with a strong political accent. We will examine how and why this change occurred and how the new concept influenced Opus Bonum itself and also the Czech exile milieu in Western Europe.
\end{abstract}

\section{Keywords}

Opus Bonum, exile, Franken, culture, politics, religion, Anastáz Opasek, Richard Belcredi, Vladimír Neuwirth 


\section{1 Úvod}

V této stati se pokusíme přiblížit jeden z hlavních mezníků v historii exilové organizace Opus bonum. Stojíme však před otázkou, jak definovat předěl, který má oddělovat kvalitativně odlišné celky. Nastává nová etapa v životě až tím, že se viditelně něco změní, nebo už tím, že o něčem začneme nově přemýšlet $\mathrm{v}$ jiných, dříve netušených souvislostech? Subjektivita zvoleného př́ístupu je evidentní a vede nás neomylně k nutnosti volby. Za zkoumaný mezník v exilové historii tohoto spolku jsme vybrali rok 1978, kdy se uskutečňuje první setkání exulantů v př́íhraniční obci Franken. ${ }^{1}$ Na dohled české zemi se zde uskutečnilo diskusní setkání, které vešlo do dějin pod názvem Setkáni vítězů a poražených. ${ }^{2}$ Proč byl zvolen právě tento rok a nikoliv rok 1972, kdy bylo Opus bonum založeno a od počátku procházelo bouřlivým zápasem o svébytnost? A proč nebyl vybrán rok 1989, kdy se zhroutil režim, který donutil většinu ${ }^{3}$ aktivních členů Opus bonum odejít z vlasti, respektive zůstat v exilu? Právě rok 1978 se stal tím historickým předělem, kterým začíná nová etapa ve vývoji spolku. Aktivity plynoucí z této změny později také přispěly k erozi režimu ve vlasti za železnou oponou.

Cílem př́íspěvku je zhodnocení, co znamená rok 1978 v Opus bonum vzhledem k předchozímu i následnému vývoji. Budeme se tázat, jaký byl dopad tohoto milníku na členskou základnu organizace, zda ovlivnil vývoj v Opus bonum disent v ČSSR a jaké byly konsekvence roku 1978 v životních osudech zakladatelů sdružení. Systematickému zpracování dějin Opus bonum se zatím téměř nikdo z badatelů nevěnoval ${ }^{4}$, s výjimkou publicisty a historika Petra Placáka, jehož publikace vyšla v roce $2020^{5}$.

K uvedenému tématu je ještě možné získat cenné vzpomínky od některých pamětníků. Uvědomujeme si úskalí subjektivity při používání orální metody, které pregnantně vyjádřila Linda Shopes: „To, že někdo u určité události byl, neznamená ještě, že plně pochopil, co se stalo. "6 Zároveň ale dodáváme, že bez vzpomínek některých aktérů by nebylo možné

1 Setkání se uskutečnilo ve dnech 23.-26. února 1978. Viz např. Pozvánka na sympozium. Archiv Národního Muzea, fond č. 26 - Sympozia Opus bonum ve Frankenu, kart. 4, složka Franken 1978.

2 Na pozvánce k tomuto setkání je uvedeno téma Československo 1945, 1948 a co bylo dál? Viz Archiv Národního Muzea, fond č. 26 - Sympozia Opus bonum ve Frankenu, kart. 4, složka Franken 1978. K rozšíření názvu Setkáni vítězu a poražených nepochybně přispěl sborník ÚNOR 1948 očima vítězů i poražených o třicet let později, který vydalo Opus bonum v nakladatelství Index v Kolíně nad Rýnem v roce 1979. Editorem svazku byl Pavel Tigrid.

3 Opus bonum bylo tvořeno zejména lidmi, kteří odešli z Československa po únoru 1948 nebo po okupaci v roce 1968. Ze 17 zakládajících členů nebyli jen 4 z nich exulanty (Richard Hackenberg, Walter Klötzl, Viktor Weiser a Josef Will). S rozrůstající se členskou základnou byl poměr exulantů ještě vyšší.

4 Dílčí odkazy lze nalézt například v publikacích zaměřených na historii idejí, konkrétněji na politiku, kulturu či náboženství v exilu: Opasek, Anastáz: Dvanáct zastaveni. Vzpomínky opata břevnovského kláštera. Praha 1997; Neuwirth, Vladimír: Vcházeni do Evropy. Praha 2008; Havelková, Miroslava: Milan „Plukovnik“ Kubes. Život jednoho exulanta v soukolí dějin. Praha 2016; Kotyk, Petr - Tigrid, Pavel: Mně se nestýskalo. Praha 2010.

5 Placák, Petr: Křestanský zápas o českou věc. Působení opata Opaska a organizace Opus bonum v československém exilu v letech 1972-1989. Praha 2020. Při přípravě této stati (srpen 2019) nebyla tato kniha ještě $\mathrm{k}$ dispozici.

6 Vaněk, Miroslav - Mücke, Pavel: Třetí strana trojúhelniku. Teorie a praxe orální historie. Praha $2015^{2}$, s. 23. 
dění v Opus bonum pochopit objektivně. Významným pramenem k uvedenému tématu je literární pozůstalost Vladimíra Neuwirtha v Archivu Slezské univerzity v Opavě, bez které lze jen těžko porozumět idejím zakladatele Opus bonum kontrastujících s aktivitami od roku 1978. Cenný vhled do osobní roviny aktérů vnesla také soukromá korespondence Vladimíra Neuwirtha s Karlem Skalickým, která byla autorovi článku poskytnuta druhým $\mathrm{z}$ autorů ke studijním účelům. Ale je třeba zmínit také fond č. 26 Sympozia Opus bonum ve Frankenu v Archivu národního muzea. A konečně, významnou pramennou základnou k tomuto tématu je také Československé dokumentační středisko, založené a spravované péčí Viléma Prečana, jednoho z hlavních aktérů Opus bonum od roku 1978.

\section{Zrod Opus bonum}

Exilovou organizaci Opus bonum založili společně laický katolický aktivista Vladimír Neuwirth $^{7}$ a opat benediktinského kláštera v Praze-Břevnově Anastáz Opasek ${ }^{8}$ v exilu v roce 1972. Oba muže spojovalo hned několik podobných rysů: oba se usilovně angažovali v rodném Československu ve prospěch katolické církve, oba si hluboce vážili kulturního díla Josefa Floriana ${ }^{9}$ ze Staré Říše, potažmo kultury obecně, a konečně, oba byli vězni komunistického režimu, kteří po sovětské okupaci zvolili raději exil, než aby riskovali další uvěznění. Zatímco Anastáz Opasek byl zatčen v září 1949 a posléze byl souzen a odsouzen na doživotí v monstrprocesu „Zela a spol.“, Vladimír Neuwirth přečkal 50. léta bez většího postihu, ale byl zatčen v lednu 1961 a následně odsouzen na čtrnáct let v nejtěžší nápravně výchovné skupině. Opasek byl propuštěn na amnestii v květnu roku 1960 a Neuwirth během pražského jara roku 1968.

Neuwirth navazuje v exilu na svoje aktivity rozvíjené před uvězněním, a sice vytváření konceptu kulturních a osvětových aktivit. Ty jsou cílené především na československou emigraci a mají za cíl připomenout a odkrýt kořeny národní identity. Opíral se při tom o výbornou znalost českých dějin a kultury, především slovesné. Přirozeným způsobem tak poukazoval na křestanskou inspiraci, která může zároveň vnést světlo do nejistého tápání emigrantů v novém a cizím prostředí. Jako žák dominikánského kněze Metoděje Habáně ${ }^{10}$ oživuje tradici tzv. Akademických týdnů, které dominikánský řád organizoval

7 Vladimír Neuwirth (1921-1998), filozof, spisovatel, překladatel, politický vězeň. Kromě celé řady studií a přednášek připravil k vydání dvě knihy deníkových záznamů. Apokalyptický deník, Frankfurt - Řím 1976 , Praha 1998, 2018 a Vcházeni do Evropy, Praha 2008. Srov. např.: Krumphanzl, Robert: Bibliografie Vladimíra Neuwirtha [online] březen 2014, dostupné z: http://www.ipsl.cz/upload/files/bibl-neuwirth.pdf, citováno 14. 8. 2019.

8 P. Anastáz Opasek (1913-1999), opat benediktinského kláštera, básník, politický vězeň. Životopisná data srov. např.: Břevnouský klášter ve 20. a 21. století. [online] 2019, dostupné z: https://www.brevnov.cz/sprava/resources/anastaz-opasek-3.pdf, citováno 14. 8. 2019.

9 Josef Florian (1873-1941) vydavatel, překladatel, katolicky orientovaný myslitel. Srov. např.: Bednářová, Jitka: Josef Florian a jeho francouzšti autoři. Brno 2006.

10 P. Metoděj Habáň (1889-1984), spisovatel, filozof a teolog, politický vězeň. Významně se věnoval studentům a zároveň působil jako tomistický filozof. Založil a redigoval Filosofickou revui a přispíval do revuí Na hlubinu, Výhledy a Akord. Srov. např.: Macek, Petr: Metoděj Habáñ. Učitel, filosof a svědek dvacátého století. Praha 2019. 
v letech 1933-1943 a znovu je obnovil po 2. světové válce. ${ }^{11}$ Poválečných Akademických týdnů se Neuwirth zúčastnil a navázal zde mnohá přátelství. Podstatou těchto akcí bylo setkávání mladých lidí, zejména studentů s významnými představiteli kulturní a sociální sféry. Osobnosti přednášely své příspěvky ve filozofické, pedagogické, sociologické a historicko-estetické sekci a příspěvky byly nahlíženy z křestanské perspektivy. Součástí programu byla také diskuse a umělecký program. ${ }^{12}$ Význam této aktivity v éře první republiky podtrhovaly patronáty, které nad Akademickými týdny převzali např. pražský arcibiskup Karel Kašpar, ${ }^{13}$ olomoucký arcibiskup Leopold Prečan ${ }^{14}$ nebo např. Paul Claudel, ${ }^{15}$ spisovatel a bývalý francouzský generální konzul v Československu. ${ }^{16} \mathrm{Na}$ tuto tradici tedy navázal Neuwirth poté, co se po krátkém pobytu ve Vídni a dvouletém působení v belgické Lovani ocitl v roce 1971 ve Frankfurtu nad Mohanem. ${ }^{17}$ Organizaci prvního exilového Akademického týdne na podzim tohoto roku už Neuwirth připravoval společně s Opaskem. Setkání se uskutečnilo v Hünfeldu u Fuldy od 24. do 30. září. Z hlediska exilu šlo nepochybně o velmi vydařený projekt. Po organizační stránce se podařilo oslovit mnoho státních i církevních subjektů s žádostí o konkrétní formu podpory. Podařilo se také rozšíŕit povědomí o setkání mezi krajany, kteří se sjeli z různých koutů Evropy. Zaslouženého ohlasu se pořadatelé dočkali ze strany českých kněží působících ve Vatikánu, zástupně od mons. Jaroslava Škarvady, ${ }^{18}$ koordinátora duchovní služby pro českou emigraci. ${ }^{19}$ Se Škarvadovými souputníky, P. Karlem Skalickým ${ }^{20}$ a P. Karlem Vránou ${ }^{21}$ pojilo Neuwirtha hluboké osobní přátelství, o kterých vypovídá osobní korespondence těchto osobností v písemné pozůstalosti Vladimíra Neuwirtha.

11 Srov. Stratil, Václav. Akademické týdny na Moravě. Vzpomínka i podnět. Olomouc 1998.

12 Tamtéž, s. 9-10.

13 Karel kardinál Kašpar (1870-1941), arcibiskup pražský.

14 Leopold Prečan (1866-1947), arcibiskup olomoucký.

15 Paul Claudel (1868-1955), dramatik, básník.

16 Srov. Stratil, V. Akademické týdny, s. 4.

17 Ve Vídni zůstává V. Neuwirth poté, co se jako účastník srpnových Vysokoškolských týdnů v Kremsmünsteru v roce 1968 dozvídá o okupaci Československa. Stal se externím spolupracovníkem Ústavu slovanské filologie. V lednu 1969 nastupuje v Ústavu pro studium střední Evropy v belgické Lovani. Rozpad univerzity na vlámskou a francouzskou část pak zpơsobil zánik jeho pracovního místa. 1. 1. 1971 nastupuje Neuwirth na místo kulturního a sociálního pracovníka zřizované Českou duchovní správou ve Frankfurtu nad Mohanem. Srov. vlastní curriculum in: Neuwirth, Vladimír: Vcházeni do Evropy. Praha 2008, s. 569-571.

18 P. Jaroslav Škarvada (1924-2010), kněz, sekretář kardinála Berana v exilu, od roku 1968 koordinátor duchovní služby českým krajanům, od roku 1983 biskup. Srov. např.: ThDr. Jaroslav Škarvada. Knihovna pražské metropolitni kapituly. [online] nedatováno, dostupné z: kpmk.eu/kpmkeu/index.php/kapitula/ clenove-kapituly/instalovani-1990-2000/137-thdr-jaroslav-skarvada, citováno 15. 8. 2019.

19 Archiv Slezské univerzity v Opavě, Pozůstalost Vladimíra Neuwirtha, sign. 19, Dopisy pro VN - S, Š, Škarvada Jaroslav, Řím, 13. 10. 1971.

20 P. Karel Skalický (nar. 1934), kněz, teolog, filozof, spisovatel, redaktor revue Studie. Emeritní profesor Papežské Lateránské univerzity a Jihočeské univerzity v českých Budějovicích. Srov. např.: Karel Skalický. Slovnik českých filosofü. [online] 2019, dostupné z: https://www.phil.muni.cz/fil/scf/komplet/skalic.html, citováno 15. 8. 2019.

21 P. Karel Vrána (1925-2004), kněz, teolog, spisovatel, filozof, profesor Papežské Lateránské univerzity, rektor bohoslovecké koleje Nepomucenum v Římě. Srov. např.: Karel Vrána. Slovnik českých filosofů. [online] 2019, dostupné z: https://www.phil.muni.cz/fil/scf/komplet/vrana.html, citováno 15. 8. 2019. 
Karlu Vránovi se Neuwirth svěřuje 27. 10. 1971, tedy měsíc po prvních akademických týdnech, že přemýšlel o názvu spolku, který hodlají založit a dospěl k názoru, že by byl vhodný název Opus bonum. Název totiž odkazuje na staroř́ńšské Dobré dílo Josefa Floriana, a přitom je název v latině srozumitelný i jiným národům. ${ }^{22}$ Opus Bonum, zapsaný spolek, pak byl oficiálně založen 10. března 1972 v působišti Vladimíra Neuwirtha, ve Frankfurtu nad Mohanem..$^{23}$ Nově vzniklý spolek se definuje jako „sdruženi lidi dobré vůle, předevšim křest’anü, lidi demokraticky smýšlejicich, kteři chtěji podle suých schopností rozširovat přinos českého a slovenského národa do evropského kulturního života a toto dèdictvi predávat mládeži, a přitom se též věnovat charitativním úkoli̊m “. ${ }^{24}$ Zároveň spolek vymezuje okruh svých aktivit takto: „Opus bonum chápe svioj úkol ve smyslu kulturním, výchovném a společenském a vyhýbá se politické činnosti. “25 Plánované aktivity zahrnovaly založení bohemistické knihovny, nakladatelskou činnost a organizování kulturních, náboženských a rekreačních programů. V plánu bylo také založení galerie propagující českou a slovenskou kulturu. Stěžejními aktivitami pak měla být Setkáni mládeže v Rohru ${ }^{26}$ a pořádání Akademických týdnů. Během zářijového Akademického týdne 1972 v Hünfeldu u Fuldy pak bylo Opus bonum veřejně představeno a byl učiněn poslední formální krok, založení občanského spolku Opus bonum. ${ }^{27}$

Od samého počátku aktivit dvojice Opasek-Neuwirth a posléze aktivit Opus bonum docházelo ke konfliktům s Českou duchovní správou v Německu. Spolupráce významného církevního představitele opata Opaska s neúnavným laikem vybaveným ohromným rozhledem a hlubokou znalostí kultury a křestanství Neuwirthem, působilo na účastníky dynamickým a svěžím dojmem. ${ }^{28} \mathrm{Z}$ hlediska České duchovní správy, reprezentované zejména dvojicí kněží Alexander Heidler ${ }^{29}$ a Karel Fořt, ${ }^{30}$ šlo ovšem o konkurenční aktivitu,

22 Viz Bakeš, Ondřej: Exilová léta Vladimíra Neuwirtha a Opus bonum. Nepublikovaná diplomová práce. Olomouc 2017, s. 45.

23 Archiv Slezské univerzity v Opavě, Pozůstalost Vladimíra Neuwirtha, sign. 60, Opus bonum.

24 Program Opus bonum, Frankfurt n. Mohanem, nedatováno. Soukromá korespondence v osobním archívu Karla Skalického. Zapůjčeno autorovi článku.

25 Tamtéž.

26 Benediktinský klášter v bavorském Rohru byl působištěm opata Anastáze Opaska po odchodu do exilu.

27 Podle tehdy platného německého právního řádu bylo nutné, aby subjekty vzniklé z občanských či církevních aktivit měly výkonný orgán, zastupující je před státem. V tomto případě to bylo Opus bonum, eingeschriebene Verein (zapsaný spolek). V jeho kompetenci byly zejména finanční záležitosti a náležitá právní úprava statut spolku. Opus bonum, bürgerliche Verein (občanský spolek) vznikl až v září 1972 a členem se mohl stát každý, kdo se ztotožňoval s cíli Opus bonum. Požadavky se v podstatě redukovaly na placení členského příspěvku a v rámci možností účasti na nějaké akci. Po vzniku občanského spolku volili jeho členové ze svých řad výkonný výbor.

28 Monsignor Škarvada Neuwirthovi napsal: „Právě mi došlo Vaše pozváni s programem Akademického týdne. Pročítal jsem ho s velkým zájmem a kulil oči nad tím, co se Vám podařilo prípravit. “ Archiv Slezské univerzity v Opavě, Pozůstalost Vladimíra Neuwirtha, sign. 19, Dopisy pro VN - S, Š, Škarvada Jaroslav, ̌̌ím, 1. 6. 1971.

29 P. Alexander Heidler (1916-1980), kněz, teolog, publicista, redaktor Rádia Svobodná Evropa. Srov. např.: Tomek, Prokop: „Otec Křrišan“ z Rádia Svobodná Evropa. In: Pamět a dějiny 2014/01, s. 99-107.

30 P. Karel Fořt (1921-2014), kněz, redaktor Rádia Svobodná Evropa. Srov. např.: Fořt, Karel - Paulas, Jan: Život voněl člověčinou. Kostelní Vydří 2007. 
která třriští síly, šíří zmatek a zpochybňuje kompetence jednotlivých aktérů. ${ }^{31} \mathrm{~S}$ odstupem času můžeme konstatovat, že pocit ohrožení stávající duchovní elity byl zesílen tím, že šlo o ohrožení z laické, nikoliv církevní organizace, jak se Opus bonum prezentovalo. ${ }^{32}$ Přítomnost opata Opaska navíc situaci neuklidnilo, protože ve svém nonkonformním způsobu pastorace ${ }^{33}$ byl spíše tím, kdo znejištoval tradiční církevní struktury, jakkoliv se rekrutovaly z řad výjimečných osobností. K dovršení míry nedorozumění docházelo k napětí mezi opatem Opaskem a Českou duchovní správou kvůli kompetencím. Opasek, vědom si své opatské benedikce, byl z hlediska struktury církve nejvyšší hodnostář českého exilu. K výkonu duchovní služby mezi českými emigranty na území Spolkové republiky Německo byl ovšem pověřen zástupce české duchovní správy P. Karel Fořt a on se zodpovídal svému zřizovateli, tedy Německé biskupské konferenci, za stav pastoračních aktivit. Napětí mezi Českou duchovní správou a Opus bonum vyvrcholilo bezprostředně po Akademickém týdnu v roce 1972. Poslední příslovečnou kapkou bylo právě založení občanského spolku Opus bonum, které očima duchovní správy rozdělovalo už tak malé české farnosti. A navíc nebyl nikdo ze stávajících kněží České duchovní správy zvolen do výkonného výboru Opus bonum. ${ }^{34}$ To v praxi znamenalo jen minimální možnost společného koordinování aktivit. Situace eskalovala nikoli přímo, ale přes mons. Škarvadu sídlícího v Římě. Z jeho pohledu se původně dobrá věc začala vyvíjet partyzánsky, bez zástupců české církve, která je v Německu autentická. ${ }^{35} \mathrm{Na}$ misku vah přibyla také pachut’ ze spolupráce s Ackermann-Gemeinde, která dostala přednost před spoluprací s vlastními krajany. ${ }^{36}$ Koncem roku 1972 se vzájemnou korespondencí zúčastněných stran a setkáním Anastáze Opaska s Jaroslavem Škarvadou i s kněžími České duchovní správy povedlo nastolit alespoň prríměří. ${ }^{37}$

31 Srov. Skalický, Karel: Evangelizátor české literárni kultury. In: Neuwirth, Vladimír: Apokalyptický deník. Praha 1998, s. 294.

32 Srov. Vladimír Neuwirth očima P. Karla Fořta. In: Bakeš, O.: Exilová léta Vladimíra Neuwirtha a Opus bonum, s. 53-54.

33 Spolupracovníci Anastáze Opaska vzpomínají na celou řadu příhod, na kterých se projevila Opaskova svobodomyslnost. Ota Filip např́klad popisuje, že Opasek vzal Filipa i s manželkou v březnu 1988 v noci do své cely, přestože všichni věděli, že to pravidla kláštera zakazují. Srov. Filip, Ota: Osmý čili nedokončený životopis. Brno 2007, s. 610-611.

34 Kněží České duchovní správy nebyli bezprostředně u vzniku Opus bonum a jejich vliv na činnost spolku byl tudíž minimální. Ideové pozadí sporu lze vnímat také jako konflikt aktivních laiků s tradičním vnímáním kněžské role. V praktické rovině bylo Opus bonum závislé na finančních příspěvcích, o které žádalo mj. i Německou biskupskou konferenci prostřednictvím České duchovní správy. Ta podmiňovala finanční podporu integrováním svých zástupců do vedení Opus bonum.

35 Viz Jaroslav Škarvada - Vladimíru Neuwirthovi. ̌̌ím, 27. 10. 1972. Soukromá korespondence v osobní dokumentaci Karla Skalického.

36 Tamtéž.

37 Srov. Vinculum. Spolupráce českých kněži. [online] Řada XVII., číslo 1, podzim 1972, s. 4, dostupné z: http://scriptum.cz/soubory/scriptum/vinculum/vinculum_rada-17_1972-73_01_1972_podzim_ocr.pdf, citováno 15. 8. 2019. 


\section{Akademické týdny}

Opus bonum mělo řadu průniků s organizací Ackermann-Gemeinde, ${ }^{38}$ založenou z řad Němců vysídlených z jejich původních domovů po 2. světové válce. Předně to byla témata domova, česko-německé vztahy, společné kulturní hodnoty a také snaha po smíření a dialogu. V roce 1973 bylo tématem Akademických týdnů výročí Tisíc let pražského biskupstvi s podtitulem Češi a Němci. Mezi hosty byl například Bohdan Chudoba ${ }^{39}$ s přednáškou na téma Křstané, komunismus a technokracie nebo německý historik původem z Děčína, Friedrich Prinz, ${ }^{40}$ který promluvil na téma Eduard Beneš a Wenzel Jaksch. V roce 1975 bylo hlavním tématem Společná Evropa - výzva $k$ naději a Karel Skalický pronesl přednášku s názvem Europa - matka revolucí. Podobná témata mohou být uchopena navýsost politicky, ale k tomu až do roku 1978 nedocházelo. Šlo spíše o akademické pojetí, které mělo prohloubit pochopení minulosti, ale nebylo primárně zaměřeno na aktivizaci členů a ovlivňování politického prostředí. ${ }^{41}$

V roce 1974 byl zvolen předsedou občanského spolku Opus bonum hrabě Richard Belcredi. ${ }^{42}$ Pod jeho pragmatickým vedením se postupně daří zprůhlednit činnost spolku pro případné sponzory, zjednodušit organizační strukturu a také přispět ke sbližování s Českou duchovní správou. S Belcrediho příchodem do vedení se výrazně aktivizují členové Opus bonum z Mnichova a posléze se polarizují názory na další směřování organizace, což mělo za důsledek rostoucí pnutí mezi frankfurtskou a mnichovskou větví. V roce 1975 se konal pátý Akademický týden v Königsteinu. Zde se sešli někteří mladší členové Opus bonum ${ }^{43}$ a podle vzpomínek jednoho z nich, Vladimíra Krtila, došlo k dohodě, kterou definoval Karel Kryl ${ }^{44}$ tak, „že by např́šstě měly být akademické týdny uspořádány bez akademiků “. ${ }^{45}$ Příležitost ke změně se naskytla na setkání Akademického týdne v září 1976. Během schůze Opus bonum došlo při projednávání nových stanov k roztržce mezi členy, kteří stáli za Neuwirthem, a těmi, kteří chtěli změnit dosavadní styl práce spolku a klonili se k otevřenějšímu pojetí Belcrediho. Do sporu v tu chvíli nijak nezasáhl opat

38 Více např. Olbert, Franz: Cesta ke smíreni: Sdruženi sudetoněmeckých katolíků Ackermann-Gemeinde. Dokumenty 1948-1991. Praha 1992.

39 Bohdan Chudoba (1909-1982), historik, politik, spisovatel.

40 Friedrich Prinz (1928-2003), historik.

41 Vladimír Neuwirth, který byl garantem a hlavním organizátorem Akademických týdnů, se systematicky vyhýbal politické rovině diskusí. V kontextu Neuwirthova celoživotního zaměření je to koherentní postoj, ale s ohledem na různorodou členskou základnu a na politický vývoj v druhé polovině 70. let byl dlouhodobě neudržitelný.

42 Richard Mořic hrabě Belcredi (1926-2015), dlouholetý redaktor Rádia Svobodná Evropa, po návrat z exilu velvyslanec ČR ve Švýcarsku. Srov. např.: Richard Belcredi. Pamět’ národa. [online] 2019, dostupné z: https://www.pametnaroda.cz/cs/belcredi-richard-1926, citována 15. 8. 2019.

43 Jádro této skupiny tvořili Karel Kryl, Richard Belcredi, Miloš Vitula a Vladimír Krtil. Viz Elšíková, Monika: Opat chuligán aneb Dobré dílo Anastáze Opaska. Kostelní Vydří 2005, s. 164.

44 Karel Kryl (1944-1994), publicista, grafik, básník, písničkář.

45 Srov. Elšíková, M. Opat chuligán, s. 164. 
Opasek, který se spíše názorově přikláněl k pojetí Belcrediho. ${ }^{46}$ Ačkoliv schůze neměla právní validitu kvůli nedodržení procesních kroků podle platných stanov, přesto měla velký dopad na další vývoj ve sdružení. Rozdělení, které se v úplnosti projevilo, bylo totiž odrazem prohlubující se názorové divergence mezi oběma hlavními aktéry Opus bonum, mezi Vladimírem Neuwirthem a Anastázem Opaskem.

Vyřešení situace v Opus bonum posléze akcelerovalo vyhlášení Charty 77. Opasek byl znepokojen myšlenkou, zda není povinností organizace vyjádřit svůj souhlas s Chartou. ${ }^{47}$ V krátké tiskové zprávě pak Opus bonum vyjadřuje Chartě 77 svou podporu:

\begin{abstract}
„Jsme přesvědčeni, že od smrti Jana Palacha je vydáni Charty 77 nejuětši události našich současných dějin [...]. Odvaha a statečnost těchto mužů a žen, mezi nimiž jsou i lidé věrící a nepolitičtí, by měla být na Západě povzbuzením všem lidem dobré vi̊le, aby tím horlivěji pracovali pro spravedlnost a svobodu $v$ duchu mezinárodnich dohod, které též Československo podepsalo. " ${ }^{48}$
\end{abstract}

Později píše Opasek Neuwirthovi: „Pro mne stejně jako pro mnoho jiných je a zůstane Charta 77 východiskem z dnešní situace na východě, bude-li ovšem nad tím vším držet svou ochrannou ruku ne papež katolíků, ale zbožný baptista Carter!“49 Začátkem července 1977 se pak koná členská schůze Opus bonum, kde jsou přijaty nové stanovy a je rozšířeno předsednictvo sdružení. Mnichovská část získala většinu ${ }^{50}$ a bylo tak formálně stvrzeno to, co bylo započato na podzim předchozího roku. V září 1977 je ústřední téma Akademických týdnů Charta 77 a její základy v minulosti. Neuwirth se jich ještě zúčastní, ale bezprostředně po nich se stahuje do ústraní, aby v roce 1978 oznámil i svůj odchod z organizace, kterou zakládal, protože se ubírá jiným směrem, než bylo zpočátku deklarováno.

\title{
4 Franken 1978
}

V únoru 1978, 30 let po převzetí moci komunisty v ČSR a 10 let po sovětské invazi do Československa, uspořádalo Opus bonum setkání v městečku Franken. Setkání se zúčastnilo kolem jednoho sta Čechů a Slováků žijících v zahraničír1 a diskutovalo se

46 V srpnu 1976 píše Opasek Belcredimu: „Po všech úvahách - to je dnešni stav mého myšleni - mèl bys mít Ty účinnějši zastoupeni ve vedeni [...], ale nevim, jak to práuně vyřš̌it. “ Archiv Slezské univerzity, pozůstalost Vladimíra Neuwirtha, sign. 60. Opus bonum. Anastáz Opasek - Richardu Belcredimu, kopie Vladimíru Neuwirthovi. Místo neuvedeno, 24. 8. 1976.

47 Tamtéž. Anastáz Opasek - všem členům Opus bonum, Rohr, 19. 2. 1977.

48 Archiv Slezské univerzity, pozůstalost Vladimíra Neuwirtha, sign. 60 Opus Bonum. Prohlášení sdružení Opus bonum k Chartě 77. Rohr, únor 1977, podepsán Anastáz Opasek.

49 Tamtéž. Anastáz Opasek-Vladimíru Neuwirthovi. Rohr, 21. 4. 1977.

50 „K dosavadním členům (Opasek, Čemus, Neuwirth) byli privoleni členové: Richard Belcredi a Jiř́ Malášek senior. “ Archiv Slezské univerzity, pozůstalost Vladimíra Neuwirtha, sign. 60, Opus Bonum. Dopis členům Opus bonum, nedatováno.

51 Předmluva P. T. [Tigrid, Pavel]: Únor 1948 očima vítězů i poražených o třicet let později. Ed. P. Tigrid. Köln 1979, s. 5. 
na téma Vývoj Československa v letech 1945-1948. Co bylo na této akci opravdu výjimečné, to výstižně charakterizoval Pavel Tigrid, ${ }^{52}$ jeden z hlavních organizátorů:

„Věru pestrá společnost: komunisté a oběti komunistů, nedávni manipulovatelé a donedávna manipulovani, nositelé vládni ideologie a jejich celoživotni odpưrci, údajni vítězové i údajni poraženi, mladši i starší, pamětnici, i ti, kteři u toho nebyli, ale chtěji vědět, věrící i atheisté, marxisté, socialisté, liberálové, konzervativci, hrstka vyznavaču trockismu či anarchismu - zhusta lidé, kteřri se dosud znali jen z potištěného papiru, nejednou nízce pomlouvačného a nenávistného. “53

Ve společné debatě se setkali zástupci levicového smýšlení, jako byl jeden z protagonistů pražského jara, tajemník ústředního výboru KSČ Zdeněk Mlynář, šachový velmistr Luděk Pachman, který se v únoru 1948 aktivně podílel na komunistickém převzetí moci, historici orientovaní původně prokomunisticky, jako byli Karel Kaplan ${ }^{54}$ a Vilém Prečan, ${ }^{55}$ nebo ekonom Radoslav Selucký ${ }^{56}$. Na straně odpůrců komunistické strany to pak byl např. režimem nenáviděný Pavel Tigrid, kněží Karel Skalický a Alexander Heidler, písničkář Karel Kryl a další spolupracovníci rádia Svobodná Evropa, Karel Jezdinskýs7 a Jaroslav Pecháček ${ }^{58}$.

Otevřenost vưči palčivým otázkám doby a ochota překročit tradiční ideologická klišé byla tak očividná, že setkání vzbudilo pozornost médií. O setkání informoval nejen francouzský Le Monde ${ }^{59}$ ale i německá média Frankfurter Allgemeine Zeitung a Süddeutsche Zeitung. Nepochybně zde zapůsobil i vliv a kontakty osobnosti, jakou byl právě Pavel Tigrid. V Tigridově působení ve frankenských setkáních se zúročily jeho aktivity a postoje, které zastával už v padesátých letech. Krátce po založení Radia Svobodná Evropa (RFE) mluvil o tom, že „tato rozhlasová stanice vypověděla komunistům boj, v němž hlavní její zbraní je pravda “ ${ }^{60} \mathrm{~V}$ praxi tak navazuje na koncept gradualismu ${ }^{61}$ prosazovaném v časopise Svědectví, který založil v roce 1956 v USA a po celou dobu trvání čtvrtletníku jej také redigoval. Gradualismus se projevoval v Tigridově podání vedením dialogu s ideovými protivníky, což ve svých důsledcích znamenalo otřesení jistotou diskutujících a destabilizaci jejich apriorních východisek. Šlo o systematické úsilí rozvolňování totalitní struktury

52 Pavel Tigrid (1917-2003), publicista, politik.

53 Tigrid, P.: Únor 1948 očima vítězů, s. 5.

54 Karel Kaplan (nar. 1928), historik.

55 Vilém Prečan (nar. 1933), historik.

56 Radoslav Selucký (1930-1991), ekonom.

57 Karel Jezdinský (1939-1998), publicista.

58 Jaroslav Pecháček (1911-1997), publicista.

59 Archiv Slezské univerzity, pozůstalost Vladimíra Neuwirtha, sign. 60 Opus Bonum. Ročenka Opus bonum, přehled činnosti 1978, nedatováno.

60 Přikládáme sekeru ke kořenưm lži. Ed. P. Blažek - R. Schovánek. Praha 2015, s. 33.

61 Linhart, Jiří: Gradualismus. In: Sociologická encyklopedie. Sociologický ústav AV ČR. Ed. Z. R. Nešpor [online]. 11. 12. 2017. Dostupné z: https://encyklopedie.soc.cas.cz/w/Gradualismus, citována 15. 8. 2019. 
pozvolnou cestou. ${ }^{62}$ Jak připomíná historik Petr Orság, Tigridův koncept gradualismu nebyl vždycky akceptován. Pro poúnorové emigranty byl dialog s komunisty nepřekonatelnou překážkou a Pavel Tigrid si jej musel obhajovat proti vůli většiny. ${ }^{63}$ To, co se jevilo koncem padesátých let jako nepřijatelné, mělo o dvacet let později nádech senzace, punc vizionářského přístupu a vůni svobodného světa. Richard Belcredi později vzpomínal na první setkání takto: „... líbil se mi Tigridi̊v př́stup. On řikal: ,Když se ve Franken sejdeme jen my poúnoroví, nic nového se už nedozvíme, v̌̌e podstatné jsme si dávno řekli, zatímco když pozveme i bývalé komunisty, mohou do diskusi vnést nový pohled. "64

Opus bonum se během necelého půl roku mezi Akademickým týdnem 1977 a setkáním ve Frankenu v únoru 1978 natolik programově i personálně proměnilo, že to svým pojetím připomíná koperníkovský obrat. Politická témata, kterým se spolek dříve vyhýbal nebo je pojímal spíše akademicky, byla najednou středem všech aktivit. Komunisté, kteří byli v očích většiny exulantů viníky současné neutěšené situace ve vlasti i u každého z nich osobně, se najednou stali vítanými partnery dialogu. ${ }^{65}$ Spíše uzavřená a dovnitř církve orientovaná organizace se najednou stala příkladem otevřenosti vưči komukoli, kdo má dobrou vůli přijímat druhé, byt by stavěli i na zcela protikladných postojích.

Otázkou, na kterou ještě nemáme uspokojivou odpověd', zůstává, jaká byla cena tohoto obratu a kdo jej inicioval. Richard Belcredi sám uvádí, že poté, co se stal předsedou Opus bonum, „vyházel většinu členů a zůstalo mu jen jeho pět věrných a dluhy “.66 Je jistě pochopitelné, že pro zamýšlené změny v profilu a aktivitách organizace bylo nutné změnit nejužší okruh spolupracovníků. Praktické provedení ale ostře kontrastuje s definicí frankenských setkání jako celoexilových. Těžko si lze představit, že donedávna aktivní člen, kterému je naznačeno, že se s ním dále nepočítá, se bude účastnit aktivit, kterým se tatáž organizace ještě před nedávnem programově vyhýbala. Tak tomu bylo v případě Vladimíra Neuwirtha a lidí, kterým konvenoval jeho styl. V Neuwirthově případu lze mluvit o „ukradeném dítěti“, které přivedl na svět, postavil ho na vlastní nohy, avšak byl vzápětí jako nežádoucí rodič odstraněn. Skalický, který se jako jeden z mála aktérů účastnil jak neuwirthovské tak post-neuwirthovské éry, uvádí, že pokud použijeme termín „ukradené dítě“ na zpo̊sob, jakým se Opus bonum vypořádalo s jedním ze zakladatelů, pak musíme zároveň dodat, že toto dítě je ukradené hned dvakrát: nejprve bylo ukradeno Neuwirthovi bez zjevných námitek Anastáze Opaska a vzápětí i Opaskovi dvojicí Belcredi-Tigrid. ${ }^{67}$ Otázkou k dalšímu výzkumu zůstává, zda koperníkovský obrat v Opus

62 Orság, Petr: $S$ komunisty se mluvi (ba i spolupracuje). Pavel Tigrid a reformní komunisté v exilu po srpnu 1968. In: Hanáková, Jitka: Pavel Tigrid. Svědek dvacátého století. Praha 2018, s. 23.

63 Tamtéž, s. 24.

64 Tamtéž, s. 30-31.

65 Pavel Tigrid o tom říká: „Po pravdě řečeno česká a slovenská emigrace dostala švunk, daleko profilovanější politický výraz, až přichodem těch, co nás porazili v osmačtyřicátém, těch, kteři byli poraženi v osmašedesátém a devětašedesátém. Teprve ti dali emigraci šmrnc, takř́kajic. Většinou bývali komunisti, strašně pilní, strašně agilni, kteř́ jinak nedovedli žit než stále něco dělat. “In Kotyk, P. - Tigrid, P.: Mně se nestýskalo, s. 18.

66 Lucuk, Vít: Richard Belcredi (1926-2015). On je náš. Př́běhy 20. století. Pamét národa. [online] 14. 5. 2012, dostupné z: https://www.pametnaroda.cz/cs/belcredi-richard-20120514-0_ citována 15. 8. 2019.

67 Rozhovor s Karlem Skalickým, audiozáznam ze dne 2. 10. 2014. Zaznamenáno na elektronické médium. V osobní dokumentaci autora práce. 
bonum byl přirozeným evolučním vývojem zdola z řad členů spolku, jak naznačuje Krylova zkratka Akademické týdny raději bez akademiki̊, nebo zda byl spíše iniciován shora, prostřednictvím vlivu pracovníků Rádia Svobodná Evropa a potažmo zájmových skupin z USA. Karel Skalický uvádí na adresu Richarda Belcrediho, že bylo přinejmenším zvláštní, že se dostal do vedení Opus bonum. Na počátku sedmdesátých let, kdy spolek vznikl, byli všichni představitelé nejužšího vedení bud' jeho zakladatelé, nebo lidé vynikající svou aktivitou na vědeckém či církevním poli. Ani jedno z těchto kritérií Richard Belcredi ale nesplňoval. Vědělo se, že má dva cestovní pasy, což v tehdejších podmínkách znamenalo, že pracoval také pro Američany. ${ }^{68}$

Ani role Anastáze Opaska v překotném vývoji let 1977 a 1978 není ještě úplně jednoznačně probádaná. S jistotou můžeme tvrdit na základě korespondence v literární pozůstalosti Vladimíra Neuwirtha, že Opasek byl již nějakou dobu nespokojen se směrem, kterým se Opus bonum ubíralo. ${ }^{69}$ Nepochybně jej unavovaly stupňující se animozity mezi frankfurtskými a mnichovskými členy Opus bonum. Opaskově činorodé a do jisté míry svobodomyslné povaze také nevyhovoval náročný akademický styl vlastní Vladimíru Neuwirthovi. A především jej muselo znejištovat, že aktivitami Opus bonum dochází k určité specializaci, určené jen pro poměrně malý okruh lidí. Opasek ale vynikal schopností spojovat lidi různých povah a odlišného světového názoru ${ }^{70}$ a dokázal jim nabídnout církev atraktivní, neodsuzující, církev, která má pochopení pro nejrůznější lidské slabosti, ale vnímá na každém z příchozích mnoho dobrého. Neuwirthova role a životní postoj byly odlišného rázu. Karel Skalický charakterizoval aktivity Opus bonum během Neuwirthova působení jako buditelské ve stylu národního obrození. ${ }^{71}$ Pro mnoho vrstevníků bylo zřejmě toto pojetí nemoderní, neaktuální, příliš odtržené od života. Naopak okruh lidí, který dokázal ocenit vnímání souvislostí a citlivost k symbolům a tradici, byl odklonem od Neuwirthovy linie rozčarován a argumentoval, že s marginalizací Neuwirthova vlivu se z organizace vytratí specifičnost, kterou do ní nikdo jiný adekvátním způsobem nevloží. ${ }^{72}$ Skalický ale velmi přivítal diskusní platformu s levicovými intelektuály i za cenu možných nedorozumění a určitého slevení z původních cílů Opus bonum. ${ }^{73}$ Jako

68 Tamtéž.

69 Richardu Belcredimu píše: „... mnoho věci neklape pro vzájemné negativni vztahy již od počátku, což mne osobně nesmirně mrzi a boli, nebot' je v tom málo křest’anského ducha. “Archiv Slezské univerzity, pozůstalost Vladimíra Neuwirtha, sign. 60 Opus Bonum. Anastáz Opasek-Richardu Belcredimu. Místo neuvedeno. 24. 6. 1976.

70 Pavel Tigrid o něm říká: „Opasek svým fantasticky šikovným, nenápadným zprosobem všecko nějak zlidštil a to v̌̌echny radikály strašně znejisti, když mu ř reknete: ,Myslím, že máte pravdu. Mýlil jsem se, promiňte. Nevěděl jsem, to je strašné، "In Kotyk, P. - Tigrid, P.: Mně se nestýskalo, s. 93.

71 Srov. rozhovor s Karlem Skalickým, audiozáznam ze dne 2. 10. 2014. Zaznamenáno na elektronické médium. V osobní dokumentaci autora práce.

72 Miloslav Čemus napsal v otevřeném dopise Opaskovi a Neuwirthovi: „Na vlastní činnost OB, kvůli které bylo Vladimírem založeno, zbývalo pokaždé velmi málo času. Navíc intence zakladatele OB se dostala - díky aktivitě představitele mnichovské skupiny - na jinou kolej ... člověku se vnucuje otázka, proč se představitel Mnichova neuplatňuje třeba v instituci Communio Bohemia Nova namísto v OB, které bere doslova Vladimírovi z rukou?" In Archiv Slezské univerzity v Opavě, Pozůstalost Vladimíra Neuwirtha, sign. 11, Dopisy pro VN - C, Č, Čemus Miloslav, místo neuvedeno. 5. 7. 1977.

73 Rozhovor s Karlem Skalickým, audiozáznam ze dne 2. 10. 2014. Zaznamenáno na elektronické médium. V osobní dokumentaci autora práce. 
poctivý intelektuál totiž přivítal možnost výměny názorů a konfrontace. Potřebu reagovat na změny v náboženské společnosti výstižně charakterizoval o mnoho let později také Tomáš Petráček: „Zcela zásadni důležitost má vědomi dějinnosti a nutnosti vyrownat se s novými výzvami pro dané náboženské, kulturni a hodnotové tradice a jejich elity. Každá náboženská tradice a příslušné společenství, které danou tradici sdili, musí reagovat na ekonomické, politické, sociálni a kulturni proměny. "74

Ze vzájemné frankenské rozpravy tzv. „vítězů a poražených z února 1948“ vzešlo společné prohlášení, signované R. Belcredim, A. Heidlerem, K. Kaplanem, A. Kratochvílem, ${ }^{75}$ Z. Mlynářem, ${ }^{76}$ A. Opaskem, L. Pachmanem, ${ }^{77}$ J. Pecháčkem, V. Prečanem, R. Seluckým, K. Skalickým, J. Slámou, ${ }^{78}$ R. Ströbingerem ${ }^{79}$ a P. Tigridem. „Setkání bylo vedeno snahou v̌̌ech účastniků překonat iluse a mýty o minulosti a současnosti Československa, "80 stálo v úvodu prohlášení. Signatáři zde komentují vývoj Československých dějin s otevřeností do té doby v Opus bonum nevídanou. Odsun německých občanů po válce charakterizují jako vítězství principu odplaty nad principem spravedlnosti, únor 1948 hodnotí jako vítězství totalitního principu. Rok 1968 vnímají jako důsledek „Vítězného února“, který se obrátil proti velké části komunistů samotných, a Chartu 77 označují za stoupence demokratických a humanitních ideálů. Východisko a smysl svého dalšího úsilí pak vidí tito političtí exulanti v nedělitelnosti lidských práv a politických svobod bez ohledu na víru, filozofické nebo politické přesvědčení. ${ }^{81}$

Charta 77, která akcelerovala příklon Opus bonum k politickým tématům, byla námětem Frankenského sympozia v roce 1979. V dalších letech pak následovala témata Vztahy mezi Čechy a Slováky, Posláni české a slovenské kultury v Evropě, 25. výroči založeni Tigridova Svědectví, Mír, mírové hnutí, křestanská etika, Československo 1984, život proti totalitě, nebo později v roce 1987 Knihy, spisovatelé, prekladatelé, nakladatelé. V roce 1989 zvolili pořadatelé př́ihodné téma s názvem Dialog nebo konfrontace? ${ }^{82}$ Paralelně se sympozii se mnozí členové snaží pomáhat disidentům v Československu zásilkami léků a také ilegálním pašováním knih. Nezůstalo jen u slov, byl čas pomáhat potřebným.

74 Petráček, Tomáš. Adaptace, rezistence, rezignace: církev, společnost a změna v novověkých dějinách. Ostrava 2013, s. 6 .

75 Antonín Kratochvil (1924-2004), spisovatel.

76 Zdeněk Mlynář (1930-1997), politik.

77 Luděk Pachman (1924-2003), šachový velmistr.

78 Jiří Sláma (1929-2020), ekonom.

79 Rudolf Ströbinger (1931-2005), spisovatel.

80 Přátelské setkání bývalých vítězů a poražených ve Frankenu (společné prohlášení). Studie, číslo 56. Křestanská akademie v Ř́mě 1978, s. 158. [online] II/1978, dostupné z: http://scriptum.cz/soubory/scriptum/studie/studie_1978_056_ocr.pdf, citováno 15. 8. 2019.

81 Srov. tamtéž.

82 Archiv Národního Muzea, fond č. 26 - Sympozia Opus bonum ve Frankenu. 


\section{Závěr}

Je jistě relevantní otázkou, zda je milníkem ve vývoji Opus bonum až rok 1978, když vývoj spolku naznačuje změnu diskursu v náznacích už od Akademického týdne roku 1975 a s jistotou nejpozději po zveřejnění Charty 77. Nicméně pro rok 1978 jakožto bod zlomu hovoří zejména recepce dějin spolku z řad vlastních členů Opus bonum, ale také výměna určité části elit, která se vztahuje k tomuto roku. Ve svých vzpomínkách se jen nepatrná část členů odkazuje na události v prvních šesti letech organizace. Z části je to nepochybně dané tím, že ti, kdo se nechtěli podílet na novém směru, odešli velmi brzy sami nebo, jak otevřeně řekl Belcredi, „byli vyhozeni“. Ti, kteří zůstali, vnímají uvedený milník jako zásadní, protože vyslal do světa jasný signál o exilu aktivním a nepředpojatě diskutujícím s lidmi odlišných ideologických postojů. O exilu, který sjednocuje lidi nejrůznějšího zaměření a není úzce konfesně vyhraněný. $O$ exilu, který reflektuje palčivé otázky doby a nemlčí k bezpráví. Anastáz Opasek zastává od tohoto přelomového roku výrazně integrující roli, která ani v dalších letech neztrácí na intenzitě. Nově formované elity sdružení mluví mimo jiné také proto o „Opaskově“ Opus bonum.

Zatímco v první etapě Opus bonum se program zaměřoval na prohlubování křestanské identity a vhodným prostředím pro tuto praxi byla kultura, v druhé etapě (po Neuwirthově rezignaci na podíl ve vedení spolku) dochází k diskusi na palčivé otázky doby, přednostně politické. Kultura hraje stále významnou roli, ale proměňuje se její vnímání. V Neuwirthově etapě jsou odkrývány křestanské inspirace i v dílech, která nejsou navýsost křestanská a autoři svým životem a dílem nezastávají programově křestanský postoj. Typické jsou Neuwirthovy interpretace Boženy Němcové, Petra Bezruče a Karla Máchy a nejmarkantněji je tento jeho př́ístup patrný v interpretaci díla J. W. Goetheho, kterému se Neuwirth začal intenzivně věnovat po odchodu z Opus bonum. Axiomu hledání křesţanských kořenů byly podřízeny i ostatní př́íspěvky v období Akademických týdnů. Nelze tvrdit, že politická témata byla do roku 1978 tabuizovaná, ale je patrné, že způsob práce s nimi byl radikálně odlišný. Nešlo přednostně o diskusi, ale spíše o naznačení souvislostí s apriorním cílem poukazovat na křestanské souvislosti. V etapě frankenských setkání, která začala v únoru 1978, šlo o konfrontaci formou korektně vedené diskuse, jejímž cílem bylo objasňování jednotlivých osobních postojů, či vývoj té které názorové skupiny. Křestanství reprezentované opatem Opaskem zaručovalo spíše etický základ, na jehož bázi se mohla setkání uskutečňovat. Osobnost Anastáze Opaska zaručovala setkáním smírlivý postoj, snahu o porozumění a důraz na osobní důstojnost zúčastněných. Tak mohlo docházet $\mathrm{k}$ vytváření nečekaných přátelských vazeb, které později výrazně napomáhaly k nalezení společného jazyka v dialogu. Také není možné přehlédnout, že v novém konceptu se do Opus bonum integrují lidé, kteří měli k církvi dříve odtažitý postoj, ale nová zkušenost s církví prostřednictvím Anastáze Opaska je přivedla k reflexi tohoto přístupu. A ten se promítl i do následných postojů v diskusi. Za všechny lze uvést právě Zdeňka Mlynáře, jehož přítomnost na bohoslužbách byla Opaskovi paradoxně přičítána k tíži jako příklad neakceptovatelného sblížení Opus bonum s komunisty. At̉ už byl obrat v zaměření iniciován zdola nebo shora, případně kombinací obou vlivư, můžeme se odvážit tvrzení, že př́klon k politickým tématům přidal Opus bonum na vážnosti 
v očích zahraničních partnerů i komunistického establishmentu ve vlasti. Organizace byla zařazena mezi ty, do kterých je třeba proniknout a které působí proti socialistickému zřízení. Příklon k politickým tématům byl ale také povzbuzením pro disent v ČSSR. V dalším vývoji organizace docházelo ke stále častějším kontaktům mezi Opus bonum a disidenty, nejprve telefonicky, poté i zasíláním příspěvků na Frankenská sympozia. I na konci osmdesátých let, kdy komunistický režim svolil a někteří spisovatelé mohli vycestovat za železnou oponu a zúčastnit se setkání Opus bonum. Organizace se tak stala silou, která podporovala nejen domácí odpůrce režimu, ale i dialog se svými oponenty.

\section{Franken 1978: Copernican Revolution in the exile organization Opus Bonum}

The aim of this contribution is to evaluate what year 1978 means for Opus bonum in relation to their previous and subsequent development. I am interested in consequences of year 1978 on the lives of association's founders. It is certainly a relevant question whether the milestone in the development of Opus bonum is only in 1978, as the development of the association suggests some changes in its direction already after the Academic Week of 1975, and with certainty at latest after the proclamation of Charter 77. The year 1978 is however considered as a turning point thanks to the reception of the history of the association by its own members, and also thanks to the exchange of a certain part of its elites.

In February 1978, thirty years after the Communist takeover of Czechoslovakia and ten years after the Soviet invasion into Czechoslovakia, Opus bonum held a meeting in a Bavarian town Franken. Since its previous public meeting during the Academic Week 1977, Opus bonum had changed so much in terms of program and personnel that it can be described as a Copernican Revolution. Political topics previously avoided or conceived rather academically were now at the center of all activities. Communists, who had in the eyes of most exile been guilty for the contemporary plight of the country and of each of them personally, became welcome partners of the dialogue. The organization which had been rather closed and oriented inwardly became an example of openness to anyone havinga good will to accept others, even those building on completely contradictory attitudes. I dare say that the move to political issues helped Opus bonum to gain an esteem in the eyes of foreign partners and of the Communist establishment in the homeland. The organization was classified as one that needs to be penetrated and which counteracts with the Socialist system. The shift to political issues was however also an encouragement for the dissent in Czechoslovakia.

Toto dílo Ize užít v souladu s licenčními podmínkami Creative Commons BY-NC-ND 4.0 International (https:// creativecommons.org/licenses/by-nc-nd/4.0/legalcode). Uvedené se nevztahuje na díla či prvky (např. obrazovou či fotografickou dokumentaci), které jsou v díle užity na základě smluvní licence nebo výjimky či omezení přislušných práv. 